\title{
Visceral Leishmaniasis in A Patient Presenting with Fever of Unknown Origin: A Case Report From a Low-endemic Region of Turkey
}

\author{
Türkiyénin Düşük Endemik Bölgesinden Nedeni Bilinmeyen Ateşle \\ Başvuran Bir Visseral Leyişmaniyaz Olgusu
}

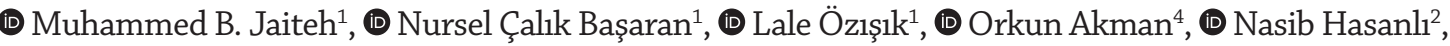 \\ (1) Sema Tortop ${ }^{3}$, (1) Büşra Betül Özmen Çapın³ , (1) Sabine Hüseyinova ${ }^{1}$, (1) Ayşegül Üner ${ }^{4}$, \\ (D) Ahmet Çağkan İnkaya² \\ ${ }^{1}$ Hacettepe University Faculty of Medicine, Department of Internal Medicine, Ankara, Turkey \\ ${ }^{2}$ Hacettepe Univesity Faculty of Medicine, Department of Infectious Diseases and Clinical Microbiology, Ankara, \\ Turkey \\ ${ }^{3}$ Hacettepe University Faculty of Medicine, Department of Microbiology, Ankara, Turkey \\ ${ }^{4}$ Hacettepe University Faculty of Medicine, Department of Pathology, Ankara, Turkey
}

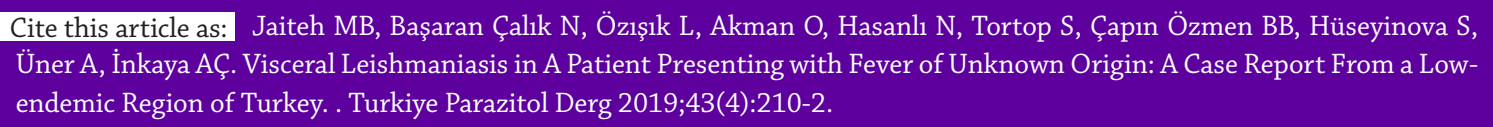

\begin{abstract}
Leishmaniasis is a neglected disease that is prevalent in tropical and subtropical regions of the world. Even though cutaneous leishmaniasis is the most common form, visceral leishmaniasis is associated with high mortality. The case presented herein is a 39 year-old bed-ridden female who presented with fever of unknown origin, tachypnea and pancytopenia. She was initially misdiagnosed as having autoimmune pancytopenia elsewhere and treated with corticosteroids and intravenous immunoglobulin. She had also received wide-spectrum antibiotics for febrile neutropenia. We performed a leishmania rK39 dipstick test which turned out to be positive along with visualisation of amastigote forms of leishmania on bone marrow biopsy. Thus, we made a diagnosis of visceral leishmaniasis and treated her with liposomal amphotericin B. Her clinical course was complicated by respiratory failure necessitating invasive mechanical ventilation. She responded well to treatment and was later extubated, shortly before being discharged. At 6 months of follow-up, no sign of recurrence was observed.
\end{abstract}

Keywords: Visceral leishmaniasis, fever of unknown origin, pancytopenia

Öz

Leyişmaniyaz, tropik ve subtropik bölgelerde sık görülen ihmal edilmiş bir hastalıktır. Kutanöz leyişmaniyaz en sık görülen formu olsa da visseral leyișmaniyaz yüksek mortalite ile ilișkili olanıdır. Bu olgu sunumunda nedeni bilinmeyen ateș, takipne ve pansitopeni ile prezente olan 39 yaşında yatağa bağımlı bir kadın hasta rapor edilmektedir. Başka bir merkezde otoimmün pansitopeni tanısı ile kortikosteroid ve intravenöz immünoglobulin tedavileri, febril nötropeni için geniş spektrumlu antibiyotik tedavisi almıştır. Hastanın merkezimizde yapılan leyişmaniyaz rK39 dipstik testi pozitif sonuçlandı ve kemik iliği biyopsisinde amastigot formları görüldü. Hastaya visseral leyişmaniyaz tanısı konularak lipozomal amfoterisin B tedavisi başlandı. Klinik seyri invaziv mekanik ventilasyonu gerektirecek solunum yetmezliği ile komplike oldu. Tedaviye iyi yanıt veren hasta ekstübe edildi ve daha sonra taburcu edildi. Taburculuktan 6 ay sonraki kontrolünde relaps bulgusu saptanmadi.

Anahtar Kelimeler: Visseral leyişmaniyaz, nedeni bilinmeyen ateş, pansitopeni

\section{INTRODUCTION}

Leishmaniasis is prevalent mainly in tropical and subtropical regions and in South Europe, and is listed among the neglected tropical diseases by the World
Health Organisation (1). Four major clinical forms of human leishmaniasis exist: cutaneous leishmaniasis (CL), visceral leishmaniasis (VL, also known as KalaAzar) including its complication of post-kala-azar

Received/Geliş Tarihi: 05.05.2019 Accepted/Kabul Tarihi: 21.10.2019

Address for Correspondence/Yazar Adresi: Muhammed B. Jaiteh MD, Hacettepe University Faculty of Medicine, Department of Internal Medicine, Ankara, Turkey

Phone/Tel: +90 5533042963 E-mail/E-Posta: muhammed.jaiteh@yahoo.com ORCID ID: orcid.org/0000-0001-9904-6663 
dermal leishmaniasis and mucocutaneous leishmaniasis (1). Estimates for CL range from 0.7 to 1.2 million cases, and for VL, this number is less than 100,000 annually (2). According to World Health Organization, more than $90 \%$ of cases between 2008 and 2010 occurred in six countries: Bangladesh, Brazil, Ethiopia, India, South Sudan and Sudan. Turkey is considered as a high-burden country for CL but not for VL $(3,4)$. Within the past 15 years, most cases have been reported from the Eastern and Southeastern Anatolian regions. Two hundred and seven VL cases were reported from Turkey between 2005 and 2014 predominantly in the Mediterranean and Aegean regions of the country (5). The main etiologic agent is Leishmania infantum (6). Here, we present a case of VL in a cerebral palsy (CP) patient presenting with fever of unknown origin (FUO).

\section{CASE REPORT}

A 39-year-old female with CP and epilepsy who hails from a rural settlement of Zonguldak (Western Black Sea Region of Turkey), initially presented at a local hospital 2 months earlier because of fever. She was diagnosed with autoimmune pancytopenia because of a positive direct Coombs, RF and a low haptoglobin levels and marked hepatomegaly. She received pulse methylprednisolone, intravenous immunoglobulin, granulocyte colony-stimulating factor and broad-spectrum antibiotics. As she did not defervesce, she was referred to our center for further investigation. On admission, she was febrile $\left(39.5{ }^{\circ} \mathrm{C}\right)$, tachypneic (30/minute), hypotensive $(90 / 60 \mathrm{mmHg})$, and tachycardic (100/minute). She was bed-ridden living with her parents and four siblings all of whom denied recent illness. Physical examination revealed an acutely ill, mentally retarded patient. A marked hepatomegaly, diminished breath sounds and mild pretibial edema were noted. Laboratory tests revealed pancytopenia with an absolute neutrophil count of $400 / \mathrm{mm}^{3}$, hypoalbuminemia (1.98 g/dL) without accompanying proteinuria, and a markedly elevated inflammatory markers (procalcitonin: $2.73 \mathrm{ng} / \mathrm{mL}$, C-reactive protein: $21.4 \mathrm{mg} / \mathrm{dL}$ and erythrocyte sedimentation rate: 27 $\mathrm{mm}$ /hour). She developed respiratory failure necessitating invasive mechanical ventilation. Abdominal imaging showed marked hepatomegaly $(20 \mathrm{~cm})$. rK39 dipstick test for Leishmania spp. was positive (Figure 1), later confirmed by microscopic examination of the bone marrow biopsy (Figure 2a, 2b). A 5-day course of liposomal amphotericin B (LAmB) at a dose of $3 \mathrm{mg}$ / $\mathrm{kg} /$ day was administered with additional doses on days 14 and 21. During follow-up she developed staphylococcal bacteremia and pneumonia which were successfully treated with adequate antibiotics. The patient was later discharged uneventfully.

\section{DISCUSSION}

This case, herein presented, highlights a case of FUO who had been erroneously diagnosed with autoimmune pancytopenia but later found to have VL. Her clinical course was complicated by respiratory failure requiring invasive mechanical ventilation.

Fever and pancytopenia are common presentations of VL. However, etiology of fever in such patients may not be apparent at the onset. This case demonstrates that VL should be suspected in cases of FUO especially when accompanied by bone marrow failure. Several case reports and series highlighted the frequent misdiagnosis associated with VL: most commonly in the form of hematological malignancies and aplastic anemia (7-9). Indeed, in certain geographical locations, $\mathrm{VL}$ is the most common infectious cause of FUO (10).

Two factors related to the case presented would have made the diagnosis of VL highly unlikely. The first is the fact that Western Black Sea Region of Turkey is a low-incidence area for

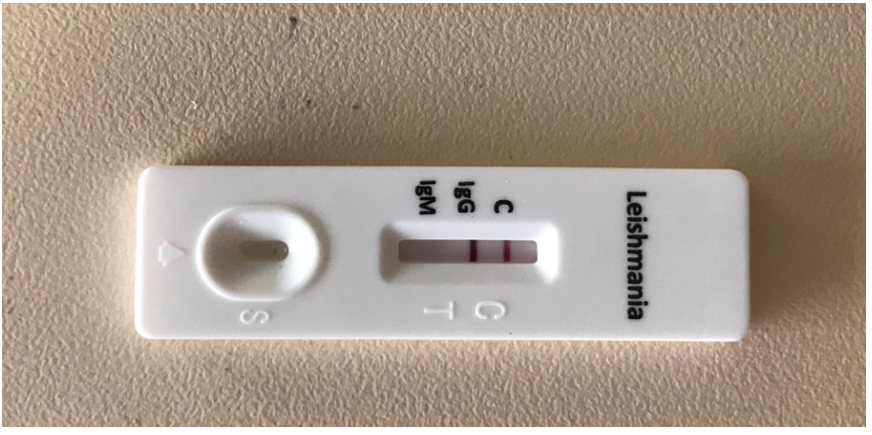

Figure 1. Rapid rK39 immunochromatographic test (dipstick test) showing positivity for Leishmania spp.

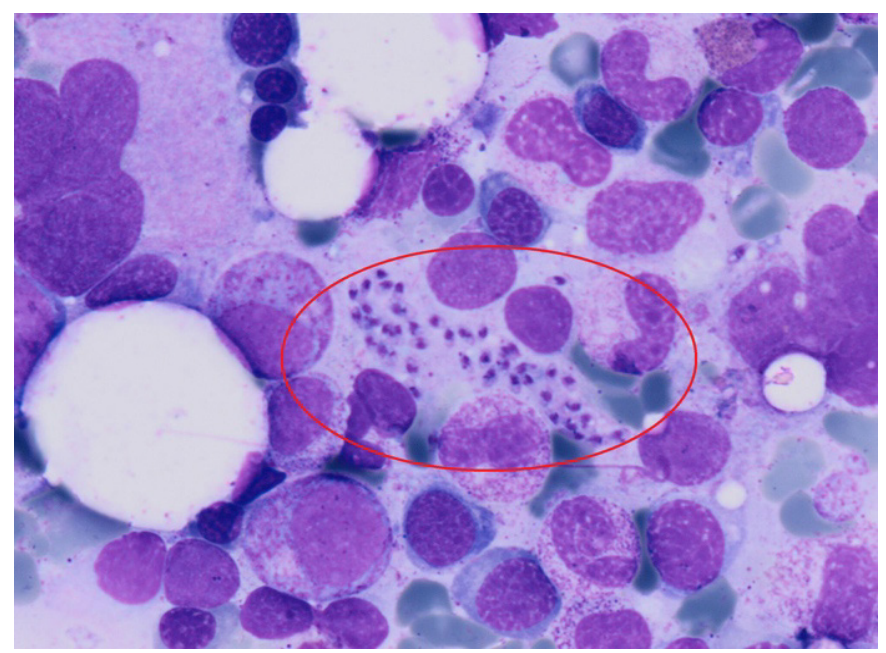

Figure 2a. Amastigote forms visualised on MGG-stained slides (shown by red oval) of bone marrow aspirate and biopsy material

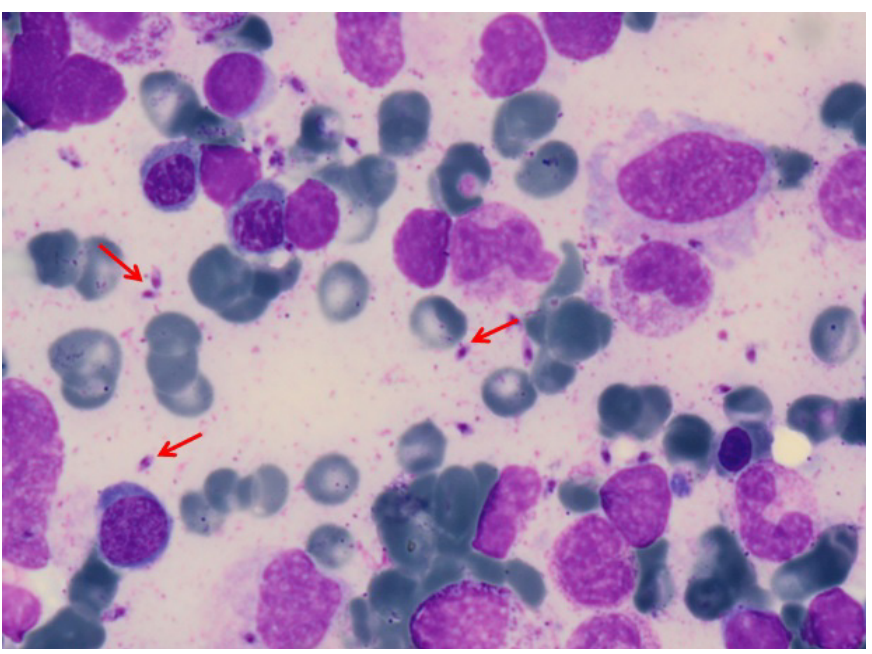

Figure 2b. Amastigote forms visualised on Giemsa-stained slides (red arrows) of bone marrow aspirate and biopsy material 
VL as opposed to the Aegean and Mediterranean Regions of the country (6). According to a WHO report, in 2013 no case of VL was reported from Zonguldak province (where the patient lived) compared to 22 cases nationwide (11). The other is the lack of a particularly high index of suspicion for VL at the beginning; which prevented specific diagnostic tests to be undertaken.

Diagnosis of VL, as discussed above, is not always straightforward. Foremost, there must be clinical suspicion followed by confirmatory laboratory tests. The presence of an otherwise unexplained fever and hepatosplenomegaly associated with cytopenia should arouse suspicion for VL. Under certain settings, especially in low-resource countries, a diagnostic algorithm based on clinical findings may be helpful. For example, a guideline prepared by the Ethiopian Government in collaboration with WHO used a case definition for VL as the presence of fever for more than 2 weeks alongside splenomegaly and/or lymphadenopathy or either wasting, anemia or leukopenia (12).

Parasitological diagnosis using bone marrow, spleen and lymph node aspirates is the gold standard to confirm VL. However, they are invasive and require qualified and trained personnel. Despite their varying sensitivity and specificity, point-of-care tests including rK39 dipstick and the direct agglutination test have the advantage of ease of use in field conditions. Other serological tests including ELISA and IFAT (which both cannot adequately diagnose relapse) and the molecular method using PCR are highly sensitive and specific, albeit costly and cannot be performed in the field (13). We used rK39 rapid test alongside bone marrow biopsy in our patient for diagnosis.

LAmB is the preferred choice of treatment for VL especially in resource-rich settings, because of its efficacy and better toxicity profiles compared to amphotericin B deoxycholate. (14). In one study, 17 patients were successfully treated with LAmB and 2 others with meglumine antimoniate (7). Other treatment options include amphotericin B deoxycholate, antimony-based compounds (sodium stibogluconate and meglumine antimoniate), paromomycin and the oral drug miltefosine (14). The patient in this case report was successfully treated with a course of LAmB.

\section{CONCLUSION}

VL is a potentially fatal parasitic disease that warrants prompt diagnosis and treatment. VL should be considered in the differential diagnosis of FUO associated with organomegaly and bone marrow failure even in non-endemic regions. Simple diagnostic algorithms could be helpful.

\section{* Ethics}

Informed Consent: A consent form was completed by all participants.

Peer-review: Externally and internally peer-reviewed.

\section{* Authorship Contributions}

Concept: M.B.J., A.Ç.İ., N.Ç.B., S.H., Design: M.B.J., A.Ç.İ., N.Ç.B., L.Ö., Analysis or Interpretation: M.B.J., A.Ç.İ., N.Ç.B., L.Ö., S.H., O.A., B.B.Ö.Ç., S.T., A.Ü., Literature Search: M.B.J., S.H., A.Ç.İ., N.Ç.B., N.H., Writing: M.B.J., S.H., A.Ç.İ., N.H., N.Ç.B., L.Ö., S.T., B.B.Ö.Ç.

Conflict of Interest: No conflict of interest was declared by the authors.

Financial Disclosure: The authors declared that this study received no financial support.

\section{REFERENCES}

1. World Health Organization. Leishmaniasis. Available from: http:// www.who.int/leishmaniasis/disease/clinical_forms_leishmaniases/en/ index2.html

2. Centers for Disease Control and Prevention (CDC). Epidemiology and Risk factors of Leishmaniasis. Available from: https://www.cdc.gov/ parasites/leishmaniasis/epi.html

3. World Health Organization. Report of a meeting of the WHO Expert Committee on the control of leishmaniases. WHO Technical Report Series: 2010 Mar. Report no.: 949.

4. World Health Organization. Leishmaniasis in high-burden countries: an epidemiological update based on data reported in 2014. Weekly Epidemiological Record 2016;91:285-96.

5. Gürel MS, Yeşilova Y, Ölgen MK, Özbel Y. Cutaneous leishmaniasis in Turkey. Turkiye Parazitol Derg 2012;36:121-9.

6. Koltas IS, Eroglu F, Alabaz D, Uzun D. The emergence of Leishmania major and Leishmania donovani in southern Turkey. Trans R Soc Trop Med Hyg 2014;108:154-8.

7. Pullukçu H, Turgay N, Işıkgöz Taşbakan M, Akyol D, Sipahi OR, Yamazhan T, et al. Fever of Unknown Origin and Visceral Leishmaniasis: a series of 20 Adult Patients. FLORA 2018;23:92-4.

8. Kawakami A, Fukunaga T, Usui M, Asaoka H, Noda M, Nakajima T ,et al. Visceral Leishmaniasis misdiagnosed as malignant lymphoma. Intern Med 1996;35:502-6.

9. Ozensoy Toz S, Sakru N, Ertabaklar H, Demir S, Sensgul M, Ozbel Y. Serological and Entomological Survey of Zoonotic Visceral Leishmaniasis in Denizli Province, Aegean Region, Turkey. New Microbiologica, 2009;32:93-100.

10. Bosilkovski M, Dimozva M, Stevanovic M, Cvetkovska VS, Duganovska M. Fever of unknown origin--diagnostic methods in a European developing country. Voinosanit Pregl 2016;73:553-8.

11. WOrld Health Organization. Available from: https://www.who.int/ leishmaniasis/resources/Turkey_CP_2014.pdf

12. Bekele T. Guideline for diagnosis, treatment and prevention of visceral leishmaniasis in Ethiopia. $2^{\text {nd }}$ ed. 2013

13. Srivastava P, Dayama A, Mehrotra S, \& Sundar S.. Diagnosis of visceral leishmaniasis. Trans R Soc Trop Med Hyg 2011;105:1-6.

14. Moore EM, Lockwood DN. Treatment of Visceral Leishmaniasis. J Glob Infect Dis 2010;2:151-8. 